Int. J. Dev. Biol. 51: 85-90 (2007)

doi: $10.1387 /$ ijdb.062165hj

Short Communication

\title{
Enhanced development of porcine embryos cloned from bone marrow mesenchymal stem cells
}

\author{
HAI-FENG JIN1,\#, B. MOHANA KUMAR 1,\#, JUNG-GON KIM ${ }^{1}$, HYE-JIN SONG ${ }^{1}$, YEON-JI JEONG ${ }^{1}$, \\ SEONG-KEUN CHO ${ }^{2}$, SIVASANKARAN BALASUBRAMANIAN ${ }^{1,3}$, SANG-YONG CHOE ${ }^{1}$ and GYU-JIN RHO*,1 \\ ${ }^{1}$ Institute of Animal Medicine, College of Veterinary Medicine, ${ }^{2}$ Division of Applied Life Science, Gyeongsang National University, Chinju, \\ Republic of Korea and ${ }^{3}$ Department of Clinics, Madras Veterinary College, Tamilnadu Veterinary and Animal Sciences University,
} Chennai, India

\begin{abstract}
In the present study, we have characterized an isolated population of porcine bone marrow mesenchymal stem cells (MSCs) for multilineage commitment and compared the developmental potential of cloned embryos with porcine MSCs and fetal fibroblasts (FFs). MSCs exhibited robust alkaline phosphatase activity and later transformed into mineralized nodules following osteoinduction. Furthermore, MSCs underwent adipogenic and chondrogenic differentiation by producing lipid droplets and proteoglycans, respectively. Primary cultures of FFs from a female fetus at $\sim 30$ day of gestation were established. Donor cells at 3-4 passage were employed for nuclear transfer (NT). Cell cycle analysis showed that the majority of MSCs in confluence were in the G0/G1 stage. Cumulus-oocyte complexes were matured and fertilized in vitro (IVF) as control. The cleavage rate was significantly $(P<0.05)$ higher in IVF than in NT embryos with MSCs and FFs $(84.5 \pm 4.6 \%$ vs. $52.2 \pm 5.4 \%$ and $50.8 \pm 5.2 \%$, respectively). However, blastocyst rates in IVF and NT embryos derived from MSCs $(20.6 \pm 2.5 \%$ and $18.4 \pm 3.0 \%)$ did not differ, but were significantly $(P<0.05)$ higher than NT derived from FFs $(9.5 \pm 2.1 \%)$. Total cell number and the ratio of ICM to total cells among blastocysts cloned from MSCs $(34.4 \pm 5.2$ and $0.38 \pm 0.08$, respectively) were significantly $(P<0.05)$ higher than those from FFs $(22.6 \pm 5.5$ and $0.18 \pm 0.12$, respectively). Proportions of TUNEL positive cells in NT embryos from FFs $(7.3 \pm 1.8 \%)$ were significantly $(P<0.05)$ higher than in MSCs $(4.6 \pm 1.3 \%)$ and IVF $(2.5 \pm 0.9 \%)$. The results clearly demonstrate that multipotent bone marrow MSCs have a greater potential as donor cells than FFs in achieving enhanced production of cloned porcine embryos.
\end{abstract}

KEY WORDS: mesenchymal stem cells, nuclear transfer, porcine

In nuclear transfer (NT), the genome of undifferentiated stem cells may be more easily reprogrammed to resemble the genome of the zygote, which may make stem cells more efficient as donors (Rideout et al., 2001). In mouse NT experiments, the developmental potential of embryonic stem (ES) cell clones was compared with somatic cell clones and despite lower blastocyst developmental rates, higher number of embryos derived from ES cells survived to term (Rideout et al., 2000, 2001; Eggan et al., 2001). However, producing cloned mice from T or B-cell lymphocytes by NT was very inefficient (Hochedlinger and Jaenisch, 2002). Quite recently, cloned mice were produced from the nucleus of natural killer T-cell lymphocytes, but not from peripheral T-cells (Inoue et al., 2005). By contrast, the extremely low cloning outcome was observed using hematopoietic stem cells demonstrating the differences in cloning efficiency, at least for cells within hematopoietic lineage (Inoue et al., 2006).

In domestic animals, technical difficulty in obtaining and maintaining an undifferentiated ES cell line has constrained the comparative studies on the cloning efficiency using ES and somatic cells. Recently, bovine mesenchymal stem cells (MSCs) isolated from bone marrow showed the developmental totipotency successfully undergoing nuclear reprogramming after NT and supported development to term (Kato et al., 2004). Cloned embryos derived from bovine and porcine undifferentiated MSCs and their derivatives along the osteogenic lineage resulted in consistently high preimplantation development compared to adult fibroblasts

Abbreviations used in this paper: ES, embryonic stem cell; FF, fetal fibroblast; ICM, inner cell mass; IVC, in vitro culture; IVF, in vitro fertilization; MSC, mesenchymal stem cell; NT, nuclear transfer.

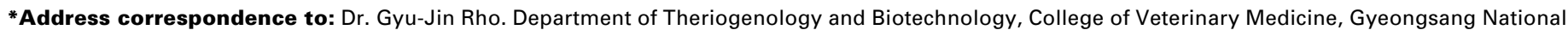
University, 900 Gazwa, Chinju, Republic of Korea 660-701. Fax: +82-55-751-5803. e-mail: jinrho@gsnu.ac.kr

\# Note: The indicated authors contributed equally to this study.
} 
(Colleoni et al., 2005). Furthermore, porcine bone marrow MSCs were able to undergo transient and stable genetic modifications with non viral and viral vectors and were found to be an attractive cell type for therapy models and for NT transgenesis (Colleoni et al., 2005; Bosch et al., 2006). Collectively, these results indicate that the characteristics of NT embryos depend on the type of nuclear donors and MSCs may have adequate reprogramming potential for NT.

Attempts have been made to determine porcine MSCs reprogramming and developmental potential of embryos by NT, but information on parameters were limited to cleavage and blastocyst formation. It is important that, the structural composition of NT embryos should also be considered as another factor responsible for the developmental obstacles since the formation of developmentally competent blastocyst involves the processes of cell division, differentiation and cell death. It has been shown that embryonic development in vitro is retarded and results in fewer cell numbers compared to those in embryos developed in vivo(Machaty etal., 1998). Embryo quality has also been linked with the number of inner cell mass (ICM) and trophectoderm (TE) cells and both cell lineages are vital and essential for embryonic and fetal survival. Apoptotic cell death during the preimplantation development stage may contribute to embryonic loss and hence its evaluation could help to achieve higher quality and survival rates in embryo production.

MSCs of bone marrow origin represent an ideal source because of their easy purification and amplification and their multipotency (Pittenger etal., 1999; Ringe etal., 2002; Colleoni et al., 2005; Bosch etal., 2006). Hence, the present study was conducted to characterize an isolated population of MSCs from porcine bone marrow by assessing their multilineage potential, to compare the developmental potential of embryos cloned with MSCs and fetal fibroblasts (FFs), cell cycle analysis of MSCs and FFs and assess the quality of embryos.

\section{Results}

\section{Isolation and multilineage differentiation of porcine MSCs}

In Experiment 1, bone marrow MSCs were efficiently isolated based on their characteristic property of attaching to plastic culture dishes and expanded in ADMEM medium. Cells appeared as single, stretched or spindle shaped with long processes leading to large clusters of stellate cells as they multiplied (Fig. 1A), with no obvious reduction in their proliferation potential.

MSCs under osteogenic conditions expressed alkaline phosphatase (AP) activity by day 12 (Fig. 1B) with a steady increase as time progressed. Mineralized matrix was evidenced by staining with von Kossa and Alizarin-red S solution (Fig. 1 C,D). At day 21, almost the whole cell layer was heavily covered with mineralized nodules. Upon induction in adipogenic media, lipid vacuoles or droplets filling the whole cytoplasm of single cells with typical characteristics of adipocytes were observed. Neutral lipid vacuoles were noticeable as early as 1 week and visualized by staining with oil red $O$ (Fig. 1E). In chondrogenic media, accumulation of sulfated proteoglycans was visualized by Alcian blue $8 \mathrm{GX}$ staining (Fig. 1F). The presence of transforming growth factor (TGF)- $\beta$ evolved a compact and homogeneous deposition of mucopolysaccharides, whereas, control MSCs exhibited a more fibrous pellet structure.

\section{Cell cycle analysis}

Experiment 2 represents the distribution of FFs and MSCs in confluent existing in the various phases of the cell cycle as deter- mined by flow cytometry. The distribution of cells at different stages of the cell cycle was similar and no significant $(P<0.05)$ differences were observed between FFs and MSCs (data not shown). The majority of FFs and MSCs (81.3 $\pm 1.2 \%$ and $78.1 \pm 0.9 \%$, respectively) were in G0/G1 stage of the cell cycle. Similar to the rates of the G0/ G1 phase, cells arrested at S or G2/M phases did not differ between FFs and MSCs $(5.8 \pm 0.3 \%, 12.9 \pm 0.4 \%$ and $6.5 \pm 0.2 \%, 15.4 \pm 0.5 \%$, respectively).

\section{Cleavage and development}

Table 1 shows the cleavage, blastocyst and total cell number of NT embryos cloned with MSCs compared with that of FFs (Experiment 3). Cleavage rate was significantly $(P<0.05)$ higher in IVF than in NT embryos with MSCs and FFs $(84.5 \pm 4.6 \%$ vs. $52.2 \pm 5.4 \%$ and $50.8 \pm 5.2 \%$, respectively). However, blastocyst rates in IVF and NT derived from MSCs (20.6 $\pm 2.5 \%$ and $18.4 \pm 3.0 \%)$
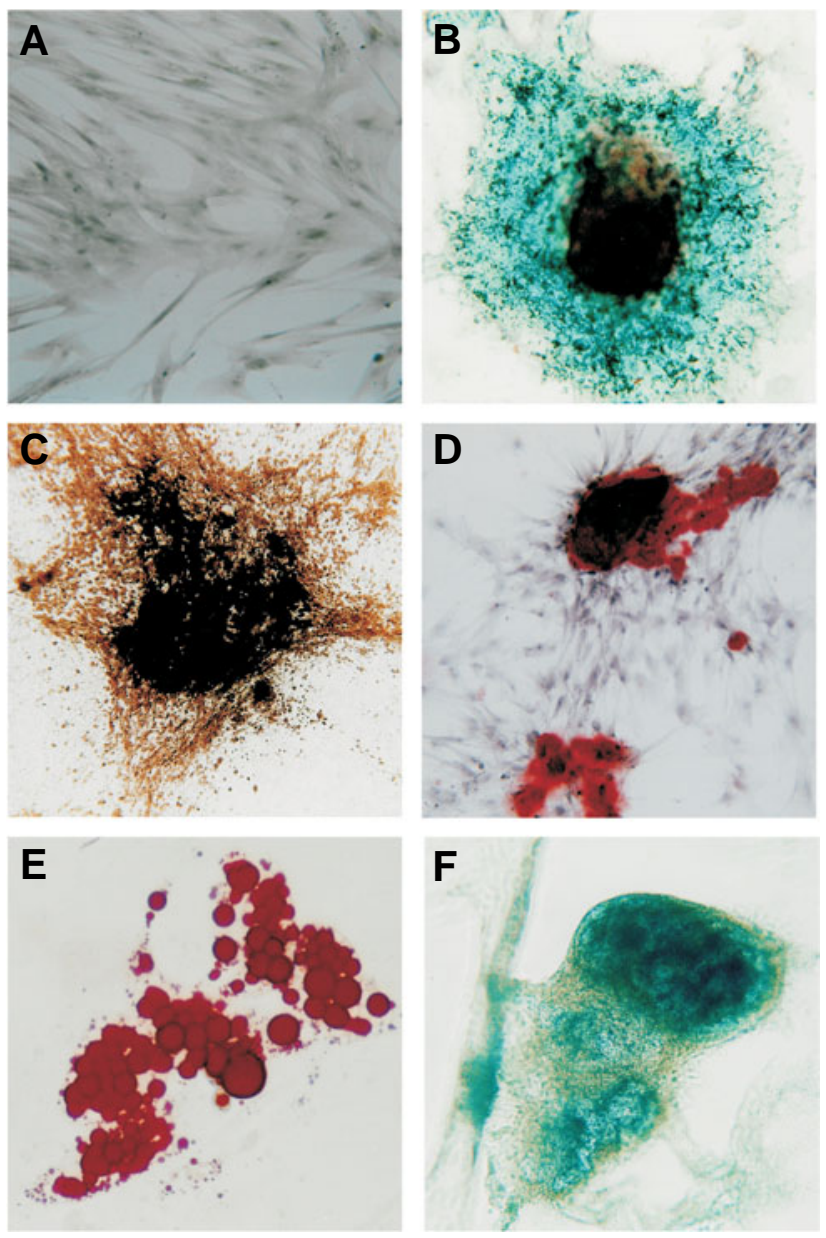

Fig. 1. Morphology and multilineage differentiation of porcine bone marrow mesenchymal stem cells (MSCs). (A) Morphological characterization of porcine bone marrow MSCs with long flattened cells of fibroblastlike shape. (B-F) Osteogenic, adipogenic and chondrogenic differentiation from porcine bone marrow MSCs. Osteogenic differentiation was evidenced by the formation of mineralized matrix as shown by visualization of alkaline phosphatase activity (B) von Kossa staining (C) and Alizarin red $S$ (D). Adipocytic differentiation was evidenced by the formation of lipid vacuoles shown by Oil red O staining (E). Chondrogenic differentiation by the presence of mucopolysaccharides was evidenced by Alcian blue $8 G X$ staining (F); (A-F), $200 X$. 
did not differ but these rates were significantly $(P<0.05)$ higher than NT derived from FFs $(9.5 \pm 2.1 \%)$. The blastocyst cell number was analyzed by labeling the nuclei with DNA stain, bisbenzimide. Total cell number of NT embryos from MSCs (34.4 \pm 5.2$)$ were significantly $(P<0.05)$ higher than that of FFs $(22.6 \pm 5.5)$.

\section{ICM ratio and apoptosis}

The results of Experiment 4 are presented in Table 2. The ratio of ICM to total cells among embryos developed in IVF and NT from MSCs $(0.45 \pm 0.03$ and $0.38 \pm 0.08$, respectively) were significantly $(P<0.05)$ higher than from FFs $(0.18 \pm 0.12)$. ICM: total cells ratio in the embryos between IVF and NT from MSCs did not differ.

Figure $2 A$ and $B$ shows the apoptotic expression of NT embryos from FFs and MSCs. All embryos produced by IVF and NT had apoptotic cells. However, proportional data of TUNEL positive cells in NT embryos from FFs $(7.3 \pm 1.8 \%)$ were significantly $(P<0.05)$ higher than from MSCs $(4.6 \pm 1.3 \%)$ and IVF $(2.5 \pm 0.9 \%)$.

\section{Discussion}

Successful NT with a variety of cell types in several species demonstrated the ability of oocyte cytoplasm to reprogram a somatic donor nucleus to a pluripotent state (Rideout et al., 2001). It has been hypothesized that the genome of undifferentiated cells, such as stem cells, may be more easily reprogrammed by the recipient oocyte. The relationship between donor cell differentiation status and NT success has been demonstrated in mice, with NT embryos derived from ES cells (Rideout et al., 2000; Eggan et al., 2001) showing significantly enhanced survival to term compared with those derived from somatic cell nuclei (Wakayama and Yanagimachi, 1999). However, Hochedlinger and Jaenisch (2002) obtained cloned mice from terminally differentiated, mature T and B-cells using a two-step method, but they never succeeded with a simple NT. Cloned mice were successfully obtained from the nucleus of natural killer T-cell lymphocytes, a lymphocyte population in their same hematopoietic lineage, but not from peripheral T cells (Inoue et al., 2005). Contrastingly, in vitro development of HSC cloned embryos was very poor and the birth rates per transfer were no better than those of clones from other somatic cell types such as cumulus, immature sertoli and fibroblast cells (Inoue et al., 2006) suggesting that, the genome of HSC may have a lower genomic plasticity, at least in terms of the ability to be reprogrammed in the MII cytoplasm after NT.

In this study, fibroblast-like appearing adherent MSCs isolated from porcine adult bone marrow were successfully induced to multipotential differentiation into osteogenic, adipogenic and chondrogenic lineages under specific culture conditions. The morphological features of MSCs were similar to the earlier observations of Ringe et al. (2002). On exposure to osteoinductive medium, MSCs transformed from a fibroblastic to a cuboidal shape, thereby exhibiting osteoblastic morphology. Uncommitted stem cells are recruited by dexamethasone towards the osteogenic lineage, presumably leading to bone cell differentiation at the expense of growth and proliferation (Vacanti etal., 2005). Further, adipogenic differentiation was apparent by the accumulation of lipid vacuoles within cells developed, coalesced and eventually filled the entire cell over a period of 3 weeks. The mechanism of action of stimulants is not completely understood and nothing is known about the mechanisms that contribute to the adipogenesis during
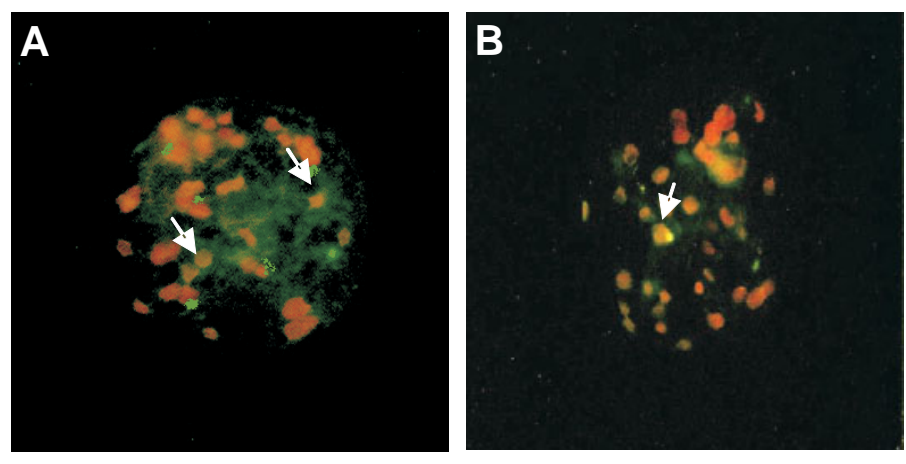

Fig. 2. Fluorescent microscopy images illustrating the apoptotic nuclei in fetal fibroblast (A) and mesenchymal stem cell (B) cloned embryos subjected to TUNEL analysis. Embryos were labeled with fluorescein isothiocyanate-conjugated dUTP (green) and propidium iodide (red). Apoptotic cells were stained with green and yellow. Arrows indicate apoptotic nuclei. (A-B) $200 \mathrm{X}$.

this spontaneous regression. However, it has been shown that, the balance between MSCs osteogenesis and adipogenesis is known to be controlled by differentially regulating mechanisms through peroxisome proliferators-activated receptor- $\gamma$, Wnt signaling cascade and the notch and RhoA signaling pathways (Vacanti et al., 2005). In this study, treatment with TGF- $\beta$ in MSCs monolayer induced chondrogenesis by an increased proteoglycan rich extra cellular matrix during culture. The functional abilities of bone marrow derived fibroblasts to differentiate under appropriate stimuli along three principal lineages: osteoblastic, adipocytic and chondrocytic allows their affirmation as MSCs (Pittenger et al., 1999).

The cell cycle analysis showed that majority of MSCs in confluent was in the G0/G1 stage, which is desirable for NT (Wilmut et al., 2002). The lower incidence of nuclear abnormalities and enhanced in vitro development of preimplantation NT embryos in pig from fetal skin derived stem cells suggested that

TABLE 1

\section{DEVELOPMENT OF IVF AND CLONED PORCINE EMBRYOS}

\begin{tabular}{lccccc}
\multicolumn{2}{l}{ Groups Donor cells } & \multicolumn{2}{c}{ Oocytes used } & \multicolumn{3}{c}{ Mean \pm SEM } \\
\cline { 3 - 6 } & & & Cleavage (\%) & Blastocyst (\%) & Total cell number \\
\hline IVF & 238 & $201(84.5 \pm 4.6)^{\mathrm{b}}$ & $49(20.6 \pm 2.5)^{\mathrm{b}}$ & $38.5 \pm 4.8^{\mathrm{b}}$ \\
NT & FFs & 242 & $123(50.8 \pm 5.2)^{\mathrm{a}}$ & $23(9.5 \pm 2.1)^{\mathrm{a}}$ & $22.6 \pm 5.5^{\mathrm{a}}$ \\
& MSCs & 255 & $133(52.2 \pm 5.4)^{\mathrm{a}}$ & $47(18.4 \pm 3.0)^{\mathrm{b}}$ & $34.4 \pm 5.2^{\mathrm{b}}$ \\
\hline
\end{tabular}

Different superscipts in the same column denote significant difference $(P<0.05) .5$ replicates.

TABLE 2

\section{APOPTOSIS AND ICM RATIO IN IVF AND CLONED PORCINE EMBRYOS}

\begin{tabular}{lcccc} 
Groups & Donor cells & Blastocysts used & \multicolumn{2}{c}{ Mean \pm SEM } \\
\cline { 4 - 5 } & & 34 & Apoptosis & ICM ratio \\
\hline IVF & 20 & $7.5 \pm 0.9^{\mathrm{a}}$ & $0.45 \pm 0.03^{\mathrm{b}}$ \\
NT & FFs & 31 & $4.6 \pm 1.8^{\mathrm{b}}$ & $0.18 \pm 0.12^{\mathrm{a}}$ \\
& MSCs & & $0.38 \pm 0.08^{\mathrm{b}}$ \\
\hline
\end{tabular}

Different superscipts in the same column denote significant difference $(P<0.05) .5$ replicates 
these embryos were more competent to undergo appropriate remodeling during early development (Zhu et al., 2004). The highest formation of morulae/blastocysts per cleaved porcine embryos reconstructed with olfactory bulb progenitor cells (23.5\% vs. $17.0 \%$ using skin stem cells and $11.6 \%$ using fibroblasts) implied that undifferentiated cells as nuclear donors may increase the efficiency of NT (Lee et al., 2006). Recently, porcine MSCs supported blastocyst development after being transferred to enucleated MII oocytes (Bosch et al., 2006). However, no significant differences were observed in the cleavage and blastocyst rates between MSCs and skin fibroblasts. Similarly, cloned embryos derived from bovine and porcine undifferentiated MSCs and their derivatives along the osteogenic lineage gave rise to consistently high preimplantation development comparable to adult fibroblasts (Colleoni et al., 2005). Further, the development of porcine NT embryos (32.9-44.7\% on day 7) using MSCs indicated that consistently high development can be obtained in vitro. In the present study, cleavage rate was significantly higher in IVF embryos than in NT embryos derived from MSCs and FFs. However, blastocyst rates in IVF and NT embryos derived from MSCs did not differ but these rates were significantly higher than that for NT embryos derived from FFs. Our observations are well in accordance with the results of above studies. However, further data on post implantation development are needed to shed more light on the effect of the stem cell nature of the donor nucleus.

In this study, total cell numbers and the ratio of ICM to total cells in NT embryos from MSCs were significantly higher than for those from FFs, but did not differ to IVF embryos. Similar were the observations of Zhu et al. (2004), suggesting that fetal stem cells derived cloned embryos are of higher quality than fibroblast cloned embryos. It is presumed that the ratio of ICM to total cells in embryos is more important for subsequent normal development after transfer than total cell number, because pig demi-embryos that had only half the cell numbers of normal embryos, but were bisected at the correct ratio of ICM to total cells, could develop to term (Tao et al., 1995).

In the present study, proportions of TUNEL-positive cells in NT embryos from FFs were significantly higher than in those from MSCs and in IVF embryos. This finding supports a relationship between incidence of cell death and developmental potential as indicated by lower developmental rate in NT embryos derived from FFs. It is well known that the postimplantation developmental potential or embryo quality is likely to be affected by apoptotic incidence during preimplantation stages. NT porcine embryos exhibited higher rates of cytoplasmic fragmentation and developmental arrest as well as higher levels of apoptotic cells than IVF embryos (Hao et al., 2003). As shown in our results, it may be possible to improve the developmental potential of NT embryos using MSCs as donors by preventing activation of the apoptotic pathway, especially during preimplantation embryo development.

In conclusion, it is demonstrated in the present study that porcine MSCs exhibit high proliferation rates and multilineage differentiation potential. NT embryos reconstructed with MSCs show enhanced developmental potential compared with those reconstructed with FFs, with a significantly higher proportion of embryos reaching the blastocyst stage. High total cell number and ICM ratio and low apoptotic positive cells were associated with NT embryos derived from MSCs. Cumulatively, this evidence suggests that MSCs have a greater potential as donor cells and are capable of driving efficiently the preimplantation development of cloned pig embryos.

\section{Materials and Methods}

All chemicals were purchased from Sigma Chemical Company (St. Louis, MO, USA) and media from Gibco (Life Technologies, Burlington, ON, Canada), unless otherwise specified.

\section{Preparation of donor cells}

Porcine female fetus was obtained via hysterectomy of pregnant gilt on day $\sim 30$ of gestation. After removal of head, limbs and visceral organs, remaining tissues were washed in Dulbecco phosphate buffered saline (DPBS) supplemented with $10 \%$ fetal bovine serum (FBS) and transferred into $0.05 \%(\mathrm{w} / \mathrm{v})$ trypsin-elthylenediamine tetra acetic acid (EDTA) solution for $5 \mathrm{~min}$. Trypsinized cells were washed once by centrifugation in Dulbecco modified Eagle medium (DMEM) by being centrifuged at $300 \times g$ for $10 \mathrm{~min}$ to take cell pellet. Fetal fibroblasts (FFs) at a final concentration of $2 \times 10^{5}$ cell/mL were then cultured in DMEM medium (high glucose) supplemented with $110 \mu \mathrm{g} / \mathrm{mL}$ Na-pyruvate and $4 \mu \mathrm{g} / \mathrm{mL}$ pyridoxine hydrochloride and $10 \% \mathrm{FBS}$ at $38.5^{\circ} \mathrm{C}$ in a humidified atmosphere of $5 \% \mathrm{CO}_{2}$ in air.

Under sterile conditions, gelatinous bone marrow was extracted from a femur of $\sim 6$ month old female pig. MSCs were isolated according to the method of Ringe et al. (2002) with minor modifications. Briefly, 3-4 g of gelatinous bone marrow was resuspended in phosphate buffered saline (PBS) and dispersed mechanically and centrifuged at $400 \times \mathrm{g}$ for $10 \mathrm{~min}$. Cells were resuspended and layered upon a Ficoll gradient (Amersham Biosciences, Uppsala, Sweden) and centrifuged at $400 \times$ gfor 30-40 min at $20^{\circ} \mathrm{C}$. The interface buffy layer was collected and washed twice with PBS and twice with advanced-DMEM (ADMEM) supplemented with $10 \%$ FBS and cultured at $38.5^{\circ} \mathrm{C}$ in a humidified atmosphere of $5 \% \mathrm{CO}_{2}$ in air. Nonadherent cells were gently rinsed off 2 days after plating. Attached MSCs reached confluency in 12-14 days after plating (passage 0 ). Once confluent, cells were dissociated using $0.1 \%(\mathrm{w} / \mathrm{v})$ trypsin-EDTA solution and pelleted at $300 \mathrm{xg}$ for $5 \mathrm{~min}$. Cells were then regrown and passaged for in vitro differentiation studies. FFs and MSCs were frozen in DMEM and ADMEM, respectively containing $10 \%$ FBS and $10 \%$ dimethyl sulfoxide (DMSO) and stored in liquid nitrogen. For NT, cells at passage 3 were thawed, cultured to reach confluency to synchronize the majority into G0/ G1 stage and subsequently used.

\section{In vitro differentiation of porcine MSCs}

Multilineage potential of porcine MSCs was evaluated by culturing firstto third-passage cells ( $2 \times 10^{5}$ cells $/ 35 \mathrm{~mm}$ dish) in ADMEM containing $10 \%$ FBS under conditions conducive for osteogenic, chondrogenic and adipogenic differentiation for 3 weeks adopting previously published protocols with minor modifications (Pittenger et al., 1999; Vacanti et al., 2005). The cells in the control groups were cultured in ADMEM supplemented with $10 \%$ FBS. Cells were stained with BCIP/NBT (Promega, Madison, WI, USA) to detect alkaline phosphatase activity. Presence of mineralized matrix was analyzed using von Kossa and Alizarin-red S stains. Cytoplasmic fat globules were identified by Oil red $O$ staining and mucosubstances by Alcian blue $8 \mathrm{GX}$ solution

\section{Cell cycle analysis}

FFs and MSCs were analyzed in 3 runs for DNA content to evaluate their stages of the cell cycle by flow cytometry (PARTEC. PA-1, Münster, Germany) using a CYSTAIN DNA 2 steps kit (PARTEC). Briefly, the separated cells $\left(1 \times 10^{6} \mathrm{cells} / \mathrm{mL}\right)$ were fixed in $70 \%$ ethanol at $4^{\circ} \mathrm{C}$ for $18 \mathrm{~h}$ and centrifuged at $200 \times g$ for $10 \mathrm{~min}$ in order to completely remove the fixative. The cells were resuspended into $21 \mathrm{mg}$ buffer reagent per $\mathrm{ml}$ extraction buffer and incubated for $15 \mathrm{~min}$ at RT with gentle shaking. Pelleted cells were stained with $2 \mathrm{~mL}$ DNA flurochrome 4, 6-diamidino-2phenylindole for minimum $1 \mathrm{~h}$ at RT and relative DNA content of each cell 
was measured and classified as G0/G1, S or G2/M phase.

\section{Oocyte collection and in vitro maturation (IVM)}

Porcine ovaries were obtained from prepubertal gilts at a local slaughterhouse and transported to the laboratory in PBS at $35-39^{\circ} \mathrm{C}$. Cumulusoocyte-complexes (COCs) were collected from follicles of 3-6 $\mathrm{mm}$ in diameter with an $18 \mathrm{G}$ needle and a $10 \mathrm{~mL}$ syringe. COCs were washed three times with nutrient mixture $\mathrm{F}-10$ (Ham-F10) and two times with in vitro maturation medium (IVM) and cultured (50 COCs/500 $\mu \mathrm{l}$ drop) in M-199 containing $5 \%$ FBS, $0.57 \mathrm{mM}$ cysteine, $10 \mathrm{ng} / \mathrm{mL}$ epidermal growth factor (EGF), $25 \mathrm{mM}$ HEPES, $2.5 \mathrm{mM}$ Na- pyruvate, $1 \mathrm{mM}$ L-glutamine, $1.0 \%$ penicillin-streptomycin $(10,000 \mathrm{IU}$ and $10,000 \mathrm{mg} / \mathrm{mL}$, respectively; PenStrep, Gibco), $0.5 \mu \mathrm{g} / \mathrm{mL} \mathrm{LH}, 0.5 \mu \mathrm{g} / \mathrm{mL}$ FSH for $22 \mathrm{~h}$ at $39^{\circ} \mathrm{C}$ in a humidified atmosphere of $5 \% \mathrm{CO}_{2}$ in air COCs were further cultured for an additional $20 \mathrm{~h}$ in the fresh IVM medium without hormone supplements.

After IVM, oocytes were freed off their cumulus cells by vortexing in DPBS medium supplemented with $0.1 \%$ (W/V) hyaluronidase for $1 \mathrm{~min}$. Oocytes with a polar body (PB) and even cytoplasm were selected for production of IVF and NT embryos.

\section{In vitro fertilization (IVF)}

Each set of 20 cumulus free oocytes were transferred into $50 \mu$ drop of modified tris-buffered medium (mTBM) consisting of $113.1 \mathrm{mM} \mathrm{NaCl}, 3.0$ $\mathrm{mM} \mathrm{KCl}, 7.5 \mathrm{mM} \mathrm{CaCl}_{2 .} 2 \mathrm{H}_{2} \mathrm{O}, 20.0 \mathrm{mM}$ Tris crystallized free base, $11.0 \mathrm{mM}$ glucose and $5.0 \mathrm{mM} \mathrm{Na}$-pyruvate, supplemented with $2 \mathrm{mM}$ caffeine and $0.04 \mathrm{~g}$ BSA (Fatty acid free, Fraction V). Oocytes were inseminated with frozen-thawed sperm prepared by Percoll (Pharmacia, Uppsala, Sweden) density gradient as described by Rosenkrans et al. (1993). The final sperm concentration was adjusted to $1 ¥ 10^{5} \mathrm{sperm} / \mathrm{mL}$. Coincubation was carried out at $38.5^{\circ} \mathrm{C}$ in a humidified atmosphere of $5 \% \mathrm{CO}_{2}$ in air for $5 \mathrm{~h}$.

\section{Nuclear transfer (NT)}

NT was carried out with minor modifications of previously described protocol (Kim etal., 2005). Denuded MII-stage oocytes were enucleated by micromanipulation technique in Hepes-buffered M-199 supplemented with $10 \%$ FBS, $7.5 \mu \mathrm{g} / \mathrm{mL}$ cytochalasin B (CCB) and $12 \mathrm{mM}$ sorbitol. Briefly, the first polar body and metaphase plate with a small volume of cytoplasm were removed together using a $15 \mu \mathrm{m}$ beveled micropipette. Single donor cell (FF or MSC) of approximately $10 \mu \mathrm{m}$ diameter was used for NT. For fusion, the reconstructed eggs were oriented in BTX Electro chamber (BTX, Inc., San Diego, CA) filled with $0.28 \mathrm{M}$ mannitol solution containing $0.1 \mathrm{mM}$ $\mathrm{MgSO}_{4}, 0.05 \mathrm{mM} \mathrm{CaCl}_{2}$ and $0.01 \% \mathrm{BSA}$ and pulsed twice with $2.0 \mathrm{KV} / \mathrm{cm}$ DC for $30 \mu \mathrm{sec}$ using a BTX Electro Square Porator (ECM 830, BTX, Inc., San Diego, CA). After fusion, eggs were cultured in $50 \mu \mathrm{L}$ drops of NCSU23 medium supplemented with $7.5 \mu \mathrm{g} / \mathrm{mL}$ CCB at $38.5^{\circ} \mathrm{C}$ in a humidified atmosphere of $5 \% \mathrm{CO}_{2}$ in air for $3 \mathrm{~h}$.

\section{In vitro culture (IVC)}

IVF and NT embryos were cultured using a protocol as previously described (Ock et al., 2006). Briefly, the presumptive zygotes (20 zygotes/ $50 \mu \mathrm{L}$ drop) were cultured in NCSU-23 (IVC-PyrLac) supplemented with 4 $\mathrm{mg} / \mathrm{mL}$ BSA, $0.17 \mathrm{mM}$ Na-pyruvate, $2.73 \mathrm{mM} \mathrm{Na}$-lactate, $20 \mu \mathrm{L} / \mathrm{mL}$ eagle amino acids in basal medium (BME) and $10 \mu \mathrm{L} / \mathrm{mL}$ nonessential amino acids in minimum essential medium (NEAA) for 2 days and further cultured in the same medium (NCSU-23, IVC-Glu) supplemented with $5.55 \mathrm{mM}$ glucose instead of Na-pyruvate and Na-lactate at $38.5^{\circ} \mathrm{C}$ in a humidified atmosphere of $5 \% \mathrm{O}_{2}, 5 \% \mathrm{CO}_{2}$ and $90 \% \mathrm{~N}_{2}$ for 5 days. Cleavage and blastocyst rates were assessed on day 2 and day 7 , respectively.

\section{Cytological analysis}

To count total cell number, day-7 IVF and NT blastocysts fixed in methanol-acetic acid (3:1) for overnight were stained with $10 \mu \mathrm{g} / \mathrm{mL}$ bisbenzimide (Hoechst 33342) in HEPES-TALP for $10 \mathrm{~min}$ and the nuclei were counted under an epifluorescence microscope (Nikon, Tokyo, Japan).
The apoptosis of embryos was detected by the Terminal Deoxynucleotidyl Transferase-Mediated dUTP Nick-End Labeling (TUNEL) method using the in situ cell death detection kit (Roche, Penzberg, Germany) following manufacturer's protocol. Briefly, blastocysts were fixed in $3.7 \%$ formaldehyde for $4 \mathrm{~h}$ at room temperature (RT), washed in PBS, permeabilized by incubation in $0.5 \%$ Triton $\mathrm{X}-100$ for $1 \mathrm{~h}$, washed in PBS, incubated with fluorescein-conjugated dUTP and terminal deoxynucleotidyl transferase enzyme for $1 \mathrm{~h}$ at $37^{\circ} \mathrm{C}$ in dark room and counterstained with $40 \mu \mathrm{g} / \mathrm{mL}$ Propidium iodide (PI) for $1 \mathrm{~h}$ at $37^{\circ} \mathrm{C}$ after treatment of $50 \mu \mathrm{g} / \mathrm{mL}$ RNase at $\mathrm{RT}$ for $1 \mathrm{~h}$. Samples were examined under an epifluorescence microscope and those stained red were nucleus and those stained green and yellow were apoptotic body.

Differential cell count was performed as described previously by Machaty et al., (1998). Briefly, blastocysts were removed of their zona pellucida using $0.5 \%(\mathrm{w} / \mathrm{v})$ pronase for $2 \mathrm{~min}$. Zona-free embryos were incubated in rabbit anti-pig whole serum diluted 1:9 (v/v) in IVC-Glu medium for $40 \mathrm{~min}$ and finally incubated in guinea pig complement diluted 1:9 (v/v) in IVC-Glu medium supplemented with $10 \mu \mathrm{g} / \mathrm{mL}$ of PI for $1 \mathrm{~h}$. Subsequently fixed in ice-cold ethanol for $5 \mathrm{~min}$ and then stained with $10 \mu \mathrm{g} / \mathrm{mL}$ of bisbenzimide in ethanol for $5 \mathrm{~min}$ at RT and observed under an epifluorescent microscope (200 X). ICM nuclei labeled with bisbenzimide appeared blue and TE nuclei labeled with both bisbenzimide and $\mathrm{PI}$ appeared pink to red.

\section{Experimental design}

The present study comprised of four experiments. In Experiment 1, isolation and characterization of adult porcine MSCs for the developmental pluripotency by multilineage differentiation were evaluated. In Experiment 2, cell cycle comparisons of stem cells (MSCs) and somatic cells (FFs) were made using flow cytometric analysis. In Experiment 3, the suitability of MSCs and FFs as nuclear donors was assessed by comparing the developmental rate and total cell number. Finally, experiment 4 examined the apoptosis and ICM ratio in embryos reconstructed with MSCs and FFs. Embryos produced by IVF were used as control.

\section{Statistical analysis}

Differences were analyzed among treatments using one-way ANOVA after arc-sine transformation of the proportional data. Data were expressed as mean \pm SEM. Comparisons of mean values among treatments were performed using Duncan's and Tukey's multiple comparisons test. Differences were considered significant at $P<0.05$.

\section{Acknowledgements}

This work was supported by Grant No. R05-2004-000-10702-0 from KOSEF, Republic of Korea.

\section{References}

BOSCH, P., PRATT, S.L. and STICE, S.L. (2006). Isolation, characterization, gene modification and nuclear reprogramming of porcine mesenchymal stem cells. Biol Reprod 74: 46-57.

COLLEONI, S., DONOFRIO, G., LAGUTINA, I., DUCHI, R., GALLI, C. and LAZZARI, G. (2005). Establishment, differentiation, electroporation, viral transduction and nuclear transfer of bovine and porcine mesenchymal stem cells. Cloning and Stem Cells 7: 154-166.

EGGAN, K., AKUTSU, H., LORING, J., JACKSON GRUSBY, L., KLEMM, M., RIDEOUT, W.M.III., YANAGIMACHI, R. and JAENISCH, R. (2001). Hybrid vigor, fetal overgrowth and viability of mice derived by nuclear cloning and tetraploid embryo complementation. Proc Nat/ Acad Sci USA 98: 6209-6214.

HAO, Y., LAI, L., MAO, J., IM, G. S., BONK, A., RANDALL, S. and PRATHER, R. S. (2003). Apoptosis and in vitro development of preimplantation porcine embryos derived in vitro or by nuclear transfer. Biol Rerpod 69: 501-507.

HOCHEDLINGER, K. and JAENISCH, R. (2002). Monoclonal mice generated by nuclear transfer from mature B and T donor cells. Nature 415: 1035-1038.

INOUE, K., WAKAO, H., OGONUKI, N., MIKI, H., SEINO, K., NAMBU-WAKAO, R., NODA, S., MIYOSHI, H., KOSEKI, H., TANIGUCHI, M. and OGURA, A. (2005). 
Generation of cloned mice by direct nuclear transfer from natural killer T cells Curr Biol15: 1114-1118.

INOUE, K., OGONUKI, N., MIKI, H., HIROSE, M., NODA, S., KIM, J. M., AOKI, F., MIYOSHI, $\mathrm{H}$. and OGURA, A. (2006). Inefficient reprogramming of the hematopoietic stem cell genome following nuclear transfer. J Cel/ Sci119: 1985-1991.

KATO, Y., IMABAYASHI, H., MORI, T., TANI, T., TANIGUCHI, M., HIGASHI, M., MATSUMOTO, M., UMEZAWA, A. and TSUNODA, Y. (2004). Nuclear transfer of adult bone marrow mesenchymal stem cells: Developmental totipotency of tissue-specific stem cells from an adult mammal. Biol Reprod70: 415-418.

KIM, Y.S., LEE, S.L., OCK, S.A., BALASUBRAMANIAN, S., CHOE, S.Y. and RHO, G.J. (2005). Development of cloned pig embryos by nuclear transfer following different activation treatments. Mol Reprod Dev 70: 308-313.

LEE, K., FODOR, W.L. and MACHATY, Z. (2006). Influence of donor cell type on the development of porcine nuclear transfer embryos. Reprod Fert Dev18: 136.

MACHATY, Z., DAY, B.N. and PRATHER, R.S. (1998). Development of early porcine embryos in vitro and in vivo. Biol Reprod 59: 451-455.

OCK, S.A., LEE, S.L., KIM, J.G., KUMAR, B.M., BALASUBRAMANIAN, S., CHOE, S.Y. and RHO, G.J. (2006). Development and quality of porcine embryos in different culture system and embryo producing methods. Zygote (in press)

PITTENGER, M.F., MACKAY, A.M., BECK, S.C., JAISWAL, R.K., DOUGLAS, R., MOSCA, J.D., MOORMAN, M.A., SIMONETTI, D.W., CRAIG, S. and MARSHAK, D.R. (1999). Multilineage potential of adult human mesenchymal stem cells. Science 284: 143-147.

RIDEOUT, W.M.III., WAKAYAMA T., WUTZ A., EGGAN K., JACKSON-GRUSBY L., DAUSMAN J., YANAGIMACHI, R. and JAENISCH, R. (2000). Generation of mice from wild type and targeted ES cells by nuclear cloning. Nat Genet24: 109110.

RIDEOUT, W.M.III., EGGAN, K. and JAENISCH, R. (2001). Nuclear cloning and epigenetic reprogramming of the genome. Science 293: 1093-1098.

RINGE, J., KAPS, C., SCHMITT, B., BUSCHER, K., BARTEL, J., SMOLIAN, H., SCHULTZ, O., BURMESTER, G. R., HAUPL, T. and SITTINGER, M. (2002). Porcine mesenchymal stem cells. Induction of distinct mesenchymal cell lineages. Cell Tissue Res 307: 321-327.

ROSENKRANS, C.F.JR., ZENG, G.Q., MCNAMARA, G.T., SCHOFF, P.K. and FIRST, N.L. (1993). Development of bovine embryos in vitro as affected by energy substrates. Biol Reprod 49: 459-462.

TAO, T., REICHELT, B. and NIEMANN, H. (1995). Ratio of inner cell mass and trophoblastic cells in demi- and intact pig embryos. J Reprod Fertil 104: 251258.

VACANTI, V., KONG, E., SUZUKI, G., SATO, K., CANTY, J.M. and LEE, T. (2005). Phenotypic changes of adult porcine mesenchymal stem cells induced by prolonged passaging in culture. J Cell Physio/205: 194-201.

WAKAYAMA, T. and YANAGIMACHI, R. (1999). Cloning of male mice from adult tailtip cells. Nat Genet 22: 127-128.

WILMUT, I., BEAUJEAN, N., DE SOUSA, P.A., DINNYES, A., KING, T.J., PATERSON, L.A., WELLS, D.N. and YOUNG, L.E. (2002). Somatic cell nuclear transfer. Nature 419: 583-586.

ZHU, H., CRAIG, J.A., DYCE, P.W., SUNNEN, N. and LI, J. (2004). Embryos Derived from Porcine Skin-Derived Stem Cells Exhibit Enhanced Preimplantation Development. Biol Reprod 71: 1890-1897.

Received: 24th March 2006 Reviewed by Referees: 18th May 2006 Modified by Authors and Accepted for Publication: 7th July 2006 Published Online: 2nd October 2006 